\title{
Leaching of rare earths from fine-grained zirconosilicate ore
}

\author{
H. Lim ${ }^{*}$, D. Ibana ${ }^{2}$, J. Eksteen ${ }^{1}$ \\ (1. Western Australia School of Mines, Curtin University, 7 Conlon Street,Waterford,6152 WA; 2.Mining and \\ Metallurgy, Western Australia School of Mines, Locked Bag 17, Kalgoorlie, 6433 WA)
}

\begin{abstract}
In this study, leaching of rare earths Y,La and Ce by sulphuric acid from fine-grained zirconosilicate ore is investigated using Taguchi method of experimental design. An orthogonal array of $\mathrm{L}_{8}, 2^{7}$ which denotes 7 factors at 2 levels is chosen to consider the various factors relevant to the leaching process: baking time, baking temperature, acid dosage, leaching time, leaching temperature, grind size and dilution. Statistical analysis showed that sulphation baking is a significant step for the leaching of rare earths from the whole-of-ground ore leach and optimized leaching of rare earths involves the following condition: baking for $3 \mathrm{~h}$ at $320^{\circ} \mathrm{C}$ at $3.2 \mathrm{~g}$ acid/g ore acid dosage followed by water leaching at $20^{\circ} \mathrm{C}$ for $1 \mathrm{~h}$ and dilution of $20 \mathrm{~mL}$ water/g ore using $300 \mathrm{um}$ grind size. The effect of each leaching factor is also discussed.
\end{abstract}

Keywords: rare earths, yttrium, lanthanum, cerium, zirconosilicate leaching, Taguchi

\section{Introduction}

Rare earths (RE) have been produced commercially from 3 major minerals: bastnasite $(\mathrm{La}, \mathrm{Ce}) \mathrm{CO}_{3} . \mathrm{F}$, monazite $(\mathrm{La}, \mathrm{Ce}) \mathrm{PO}_{4}$ and xenotime $\mathrm{YPO}_{4}{ }^{[1]}$. With the impetus from recent supply shortages, alternative sources of rare earths had been looked into ${ }^{[2-3]}$. Growing interest has been placed into zirconosilicate minerals due to its relatively higher content of the much sought after heavy rare earths and relatively lower content of associated radioactive elements thorium (Th) and uranium (U) ${ }^{[4]}$.

Zirconosilicates are altered zirconium(Zr)-bearing minerals formed in alkali environment where it is naturally enriched with rare earths, alkali and alkaline-earth cations, large anions, hydronium and water molecules $^{[5-6]}$. There are a hundred classes of zirconosilicate minerals classified according to the topological arrangement of the silicon-oxygen tetrahedra and octahedra but the minerals with known REE substitution include catapleiite $\mathrm{Na}_{2} \mathrm{ZrSi}_{3} \mathrm{O}_{9}\left(\mathrm{H}_{2} \mathrm{O}\right)_{2}$, elpidite $\mathrm{Na}_{2} \mathrm{Zr}\left(\mathrm{Si}_{6} \mathrm{O}_{15}\right) \cdot 3 \mathrm{H}_{2} \mathrm{O}$, eudialyte $\mathrm{Na}_{12} \mathrm{Ca}_{6} \mathrm{Fe}_{3} \mathrm{Zr}_{3} \mathrm{Si}_{24} \mathrm{O}_{69}(\mathrm{OH})_{3} \mathrm{Cl}$ and lovozerite $\mathrm{Na}_{3} \mathrm{H}_{5} \mathrm{ZrSi}_{6} \mathrm{O}_{18}{ }^{[7-10]}$. In most polymetallic ore, these minerals form along with other rare earth and rare metal niobium $(\mathrm{Nb})$-bearing minerals ${ }^{[11]}$.

Zirconosilicates are originally sourced as a minor mineral of $\mathrm{Zr}$ and leaching by concentrated sulphuric acid has been the major treatment route used in recovery of $\mathrm{Zr}$ values ${ }^{[12]}$. Early studies reported that the recovery of rare earths from these minerals is of secondary importance and that the recovery values are variable depending on ore chemistry and certain factors as acid dosage and dilution. Being a recent area of interest, there is very limited information with regards to the processing details of rare earths on leaching of zirconosilicate minerals. Present literature are mainly commercial in nature and highlights only the generic process of treatment which either involves the use of sulphation baking ${ }^{2}$ to convert

\footnotetext{
* Corresponding author: hazel.lim@postgrad.curtin.edu.au; WASM Office ,Curtin University,7 Conlon Street,Waterford,6152 WA; +61 -0892667738

${ }^{2}$ Sulphation baking is the term used in this report to denote low temperature heating of ore or mineral concentrate in the presence of sulphuric acid to effect sulphation reactions at the liquid -solid state as opposed to the gaseous-solid reactions in roasting processes
} 
rare earths in the zirconosilicate minerals into water soluble sulphates followed by water leaching or the use of weak sulphuric acid for direct leaching of $Z r$ and RE values without the need for sulphation baking [13-15]. For example, pilot-plant recovery of rare earths from Greenland's Kvanefield eudialyte flotation concentrate involves leaching continuously for $5 \mathrm{~h}$ using weak sulphuric acid followed by strong acid leach for $4 \mathrm{~h}$ at $90-95^{\circ} \mathrm{C}$ with $354 \mathrm{~kg} / \mathrm{T}(0.354 \mathrm{~g} / \mathrm{g})$ acid and free acidity of $110 \mathrm{~g} / \mathrm{L}$ with high RE recoveries but there is no details as to how the leaching factors affects RE dissolution ${ }^{[16]}$. On a similar note, labscale treatment of RE in columbite and gel zircon concentrate from Brockman, Western Australia makes use of sulphation baking at $750 \mathrm{~kg} / \mathrm{T}(0.750 \mathrm{~g} / \mathrm{g})$ sulphuric acid at $275^{\circ} \mathrm{C}$ for $1 \mathrm{hr}$ and grind size of $20 \mathrm{um}$ followed by water leaching at density of $3 \mathrm{~L} / \mathrm{kg}$ ore at temperature of $80^{\circ} \mathrm{C}$ for $1 \mathrm{~h}$ but RE leaching recoveries and effect of leaching factors remains undisclosed ${ }^{[17]}$. Also, most commercial reports provide mainly for leaching information of large-grained zirconosilicates from which a mineral concentrate can be easily prepared.

It is of interest therefore to study leaching conditions including the effect of leaching factors for the recovery of RE from fine-grained zirconosilicate material where mineralization requires the treatment of whole-of-ground ore and thereby involves larger lixiviant volume. The leaching conditions are expected to vary considerably to account for a more complex mineralogy associated with fine-grained mineralization and higher content of gangue minerals.

\section{Materials and Method}

The ore used in this experiment is a zirconosilicate ore of Australian source. A combination of X-ray diffraction (Bruker D8 Advance with copper target), scanning electron microscope with energy dispersive spectrometer (Zeiss Evo $40 \mathrm{XVP}$ ) and electron probe microanalysis (JEOL JXA-8530F Hyperprobe) were used to determine the mineralogy of rare earths including host rock chemistry in the sample. The excitation voltage was $20 \mathrm{KV}$, beam current at 50nA and beam diameter at 1um. Wavelengths and standards used were $\mathrm{La} L \alpha\left(\mathrm{LaPO}_{4}\right), \mathrm{F} K \alpha$ (Durango apatite), $\mathrm{Cr} K \alpha(\mathrm{Cr}$ ), Eu $\mathrm{L} \alpha$ (REE1), $\mathrm{Zr}$ $\mathrm{L} \alpha$ (Zircon), Ce $\mathrm{L} \alpha\left(\mathrm{CePO}_{4}\right), \mathrm{Mg} K \alpha$ (springwater olivine), Er L $\alpha\left(\mathrm{ErPO}_{4}\right), \mathrm{Mn} K \alpha$ (Spessartine), Nb L $\alpha$ $\left(\mathrm{CaNb}_{2} \mathrm{O}_{6}\right), \mathrm{Pr} L \alpha\left(\mathrm{PrPO}_{4}\right), \mathrm{Al} K \alpha$ ( Corundum), Tb $\mathrm{L} \alpha\left(\mathrm{TbPO}_{4}\right), \mathrm{Fe} K \alpha$ (magnetite), Nd $L \alpha\left(\mathrm{NdPO}_{4}\right), \mathrm{Si} K \alpha$ (wollastonite), Tm $L \alpha\left(\mathrm{TmPO}_{4}\right), \mathrm{Dy} L \alpha\left(\mathrm{DyPO}_{4}\right), \mathrm{Th} M \alpha(\mathrm{ThO} 2), \mathrm{Sm} \mathrm{L \alpha}\left(\mathrm{SmPO}_{4}\right), \mathrm{P}\left(\mathrm{LaPO}_{4}\right), \mathrm{Yb} L \alpha\left(\mathrm{YbPO}_{4}\right), \mathrm{Hf}$

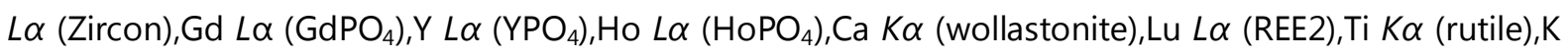
$\mathrm{K} \alpha$ (orthoclase) and $\mathrm{Zn} L \alpha(\mathrm{ZnO})$. Quantitative analysis was done by Xray diffraction method (Panalytical MagiX Fast, Netherlands).

A split sample of the ore was pulverized by ring mill for larger grind size of 300um and ISA mill for finer grind size of 10um and screened passing the desired grind size with no pre-concentration done. Increment sampling was done to prepare $20.0 \mathrm{~g}$ sample mass. Leaching tests were carried out with the use of reagent grade sulphuric acid (Analar, 98.07\%) and deionized water of equivalent 16 megohm purity. Heating and leaching were performed in single-capacity heaters and stirrers with temperature monitoring on baking done using dial-type surface thermometers (PTC Instruments, model 314C) and validated using a digital thermoprobe (307 ECE digital thermometer). Leaching temperature was measured from the solution temperature and monitored at regular intervals using an alcohol-type glass thermometer $\left(0-110^{\circ} \mathrm{C}\right.$ range).

Liquid samples were diluted and analysed by ICP-MS (MS Agilent 7700, Japan) method. Solid samples were washed with warm deionized water, oven-dried and pulverized for fusion in sodium peroxide and 
analysed by ICP-MS. Rare earths analysis is limited to Y,La and Ce being the major RE elements in the ore sample.

For this experiment, acid stoichiometric requirement was calculated based on the assumption that the following sulphation reaction occurs for $\mathrm{RE}, \mathrm{Zr}, \mathrm{Nb}$ and for impurities iron, potassium, aluminum, sodium, magnesium and calcium based on the generalized reaction:

$\mathrm{M}_{\mathrm{x}} \mathrm{O}_{\mathrm{y}}+\mathrm{nH}_{2} \mathrm{SO}_{4} \rightarrow \mathrm{M}_{\mathrm{x}}\left(\mathrm{SO}_{4}\right)_{\mathrm{y}}+\mathrm{nH}_{2} \mathrm{O}$

This value was calculated to be $396 \mathrm{mg}(216 \mu \mathrm{L})$ of concentrated sulphuric acid per $\mathrm{g}$ of ore.

\subsection{Experimental design}

The Taguchi method of experimental design was chosen to account for the many factors monitored in this leaching experiment. This method makes use of the concept of orthogonal array such that it is possible to run a portion only of the total number of possible experiments and thus provides the advantage of being cost-effective ${ }^{[18-20]}$. A standard design of orthogonal array $\mathrm{L}_{8},\left(2^{7}\right)$ which denotes 7 factors, at 2 levels, is chosen, with 2 replicates to ensure reliability of result. Table 1 shows the selected orthogonal array with the factors and its setting. Several exploratory tests based on the applicable factors were done to determine low and high test setting, for example, acid dosage is chosen to ensure that wetting of the whole ground mass is ensured particularly for larger surface area requirement of finer grind size at 10um such that low acid dosage is at $0.4 \mathrm{~g}$ acid/g of ore and high acid dosage is at $3.2 \mathrm{~g}$ acid/g of ore. The latter acid dosage level is considered very high as compared to reported dosages but it is important to provide for reasonable wetting of fine-ground ore. Agitation speed during leaching was kept at $500 \mathrm{rpm}$ for 300 um grind size and $300 \mathrm{rpm}$ for $10 \mathrm{um}$ grind size.

In Taguchi's method, the deviation of the response variable from its target value is measured through a loss function $[L(y)]^{[21]}$ as represented by:

$L(y)=k(y-m)^{2}$

where $\mathrm{k}$ is the proportionality constant, $\mathrm{y}$ is the experimental value obtained for each trial and $\mathrm{m}$ represents the target value.

For this leaching test, the response variables monitored are the leaching rates of $\mathrm{Y}$, La and Ce. These elements were chosen being the major RE constituents in the ore. The desired quality characteristic is "bigger is better" where higher leaching in water is desired and the loss function can be written as

$L(y)=k\left(1 / y^{2}\right)$

Analysis of data was done using statistical software DOE ++ version 9 (Reliasoft Corporation). Analysis of variance (ANOVA) at confidence level of $95 \%$ was used to determine which factors were significant for each response variable. Main effects plot was used to graphically display the data means of each factor at the high and low level setting of each experiment run. 


\begin{tabular}{|l|c|c|c|c|c|c|c|c|c|c|}
\hline \multicolumn{2}{|c|}{ Design of Experiments } & \multicolumn{3}{c|}{$\mathrm{L}_{8}$} & \multicolumn{5}{c|}{ Run number } \\
\hline Factor Name & $\begin{array}{r}\text { Level } \\
1(-)\end{array}$ & $\begin{array}{r}\text { Level } \\
2(+)\end{array}$ & 1 & 2 & 3 & 4 & 5 & 6 & 7 & 8 \\
\hline baking temperature, ${ }^{\circ} \mathrm{C}\left(+/-20^{\circ} \mathrm{C}\right)$ & 200 & 320 & - & - & - & - & + & + & + & + \\
\hline baking time, $\mathrm{h}$ & 1 & 3 & - & - & + & + & - & - & + & + \\
\hline Acid to ore dosage, $\mathrm{g} / \mathrm{g}$ & 0.4 & 3.2 & - & - & + & + & + & + & - & - \\
\hline leaching time, $\mathrm{h}$ & 1 & 3 & - & + & - & + & - & + & - & + \\
\hline leaching temp, ${ }^{\circ} \mathrm{C}\left(+/-5^{\circ} \mathrm{C}\right)$ & 20 & 70 & - & + & - & + & + & - & + & - \\
\hline water to ore ratio, $\mathrm{mL} / \mathrm{g}$ & 5 & 20 & - & + & + & - & - & + & + & - \\
\hline grind size, $\mu \mathrm{m}$ & 10 & 300 & - & + & + & - & + & - & - & + \\
\hline
\end{tabular}

Table 1- Experimental plan table showing leaching factors and test conditions

\section{Results and discussion}

\subsection{Material Characterization}

The zirconosilicate ore used in this experiment had the following composition as analysed by ICP-MS and XRF (wt\%): $\mathrm{SiO}_{2} \quad 63.4, \mathrm{Al}_{2} \mathrm{O}_{3} \quad 12.6, \mathrm{Fe}_{2} \mathrm{O}_{3} \quad 7.3, \mathrm{Na}_{2} \mathrm{O} \quad 4.9, \mathrm{~K}_{2} \mathrm{O} \quad 4.4, \mathrm{MnO} \quad 0.5, \mathrm{MgO} \quad 0.2, \mathrm{CaO} \quad 0.5, \mathrm{TiO}_{2} \quad 0.1$, $\mathbf{Z r O}_{2} \mathbf{1 . 8 7}, \mathbf{N b}_{2} \mathbf{O}_{5} \mathbf{0 . 4}, \boldsymbol{R E}_{2} \mathbf{O}_{3}$ 1.0. In total REO (wt\% oxides): $\mathrm{Y} \mathrm{14,} \mathrm{La} \mathrm{23,} \mathrm{Ce} \mathrm{34,} \mathrm{Nd} \mathrm{15,} \mathrm{Pr} \mathrm{5,} \mathrm{Dy} \mathrm{2,Sm} \mathrm{2,} \mathrm{Gd}$ 2. Xray diffraction determination provided major ore minerals as follows (wt\%): albite $\mathrm{NaAlSi}_{3} \mathrm{O}_{8} 40.5$, microcline $\mathrm{KAISi}_{3} \mathrm{O}_{8}$ 27.1, quartz $\mathrm{SiO}_{2} 17.1$ and aegirine $\mathrm{NaFe}^{+3} \mathrm{Si}_{2} \mathrm{O}_{6}$ 8.2.

Yttrium along with few La and Ce are detected in armstrongite and more in eudialyte-like mineral matrix in weight content of $0.1-0.5 \%$ in the mineral grains. These grains appear as porous shapeless aggregates that are closely intergrown with the gangue minerals, forming a continuous and cemented network of mineralization along the matrix of the ore. The largest aggregate are about $20 \mu \mathrm{m}$ in diameter but most individual grains are less than $5 \mu \mathrm{m}$ as shown in the micrograph in Fig. 1. Light rare earths $\mathrm{La}$ and $\mathrm{Ce}$ elements exist also as bastnasite- $\mathrm{Ce},(\mathrm{Ce}, \mathrm{La}) \mathrm{CO}_{3} \mathrm{~F}$ grains ranging in size from less than $10 \mu \mathrm{m}$ to larger grains at $100 \mu \mathrm{m}$ (Fig. 2). Bastnasite mineral grains have well-defined crystal shape and with consistent microprobe spectrum. 

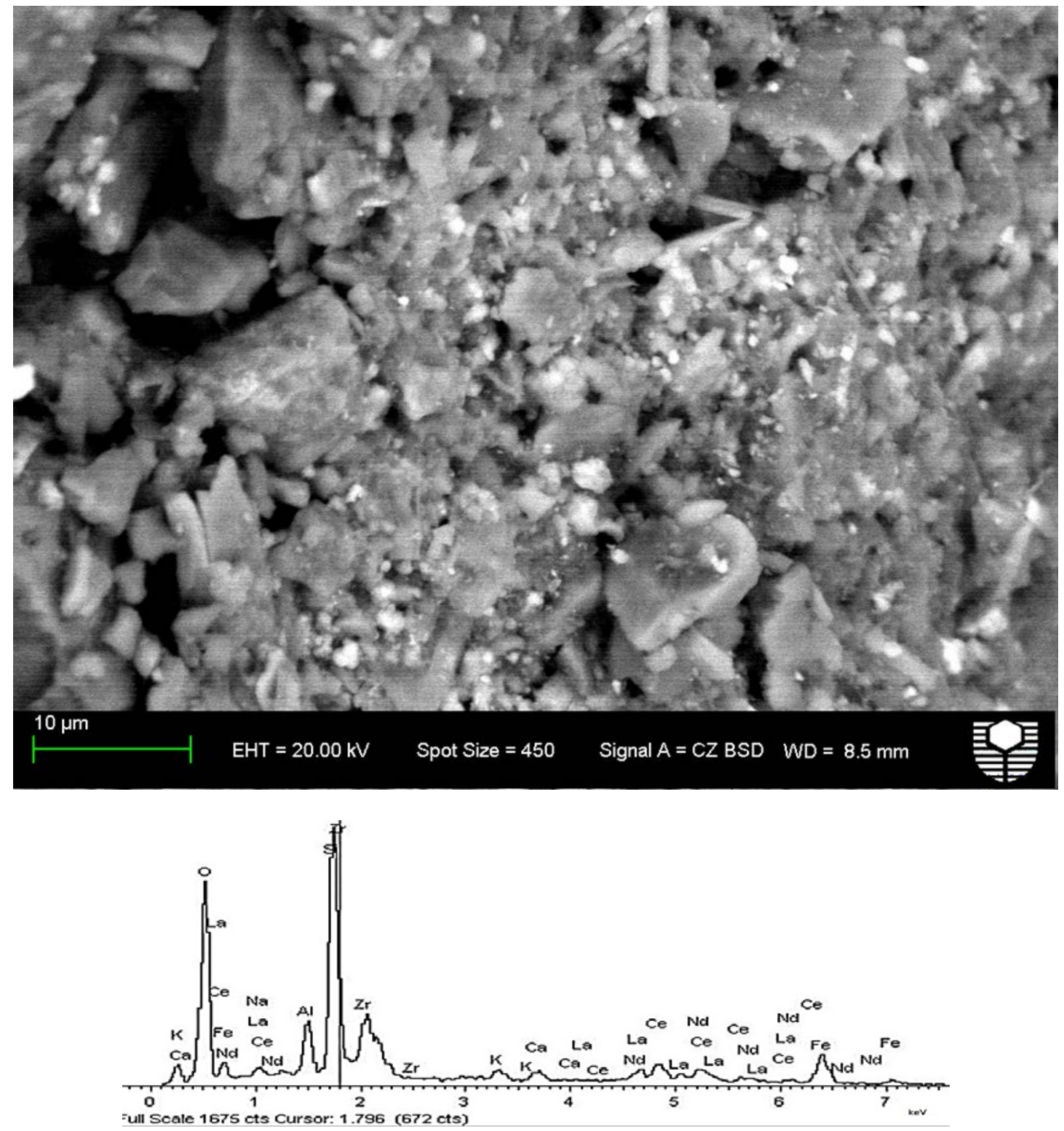

Fig. 1 Back-scattered SEM micrograph showing fine-grained (<5um) bright zirconosilicate mineral grains in contrast with the dull-coloured silicate matrix with the EDS analysis shown at bottom. 

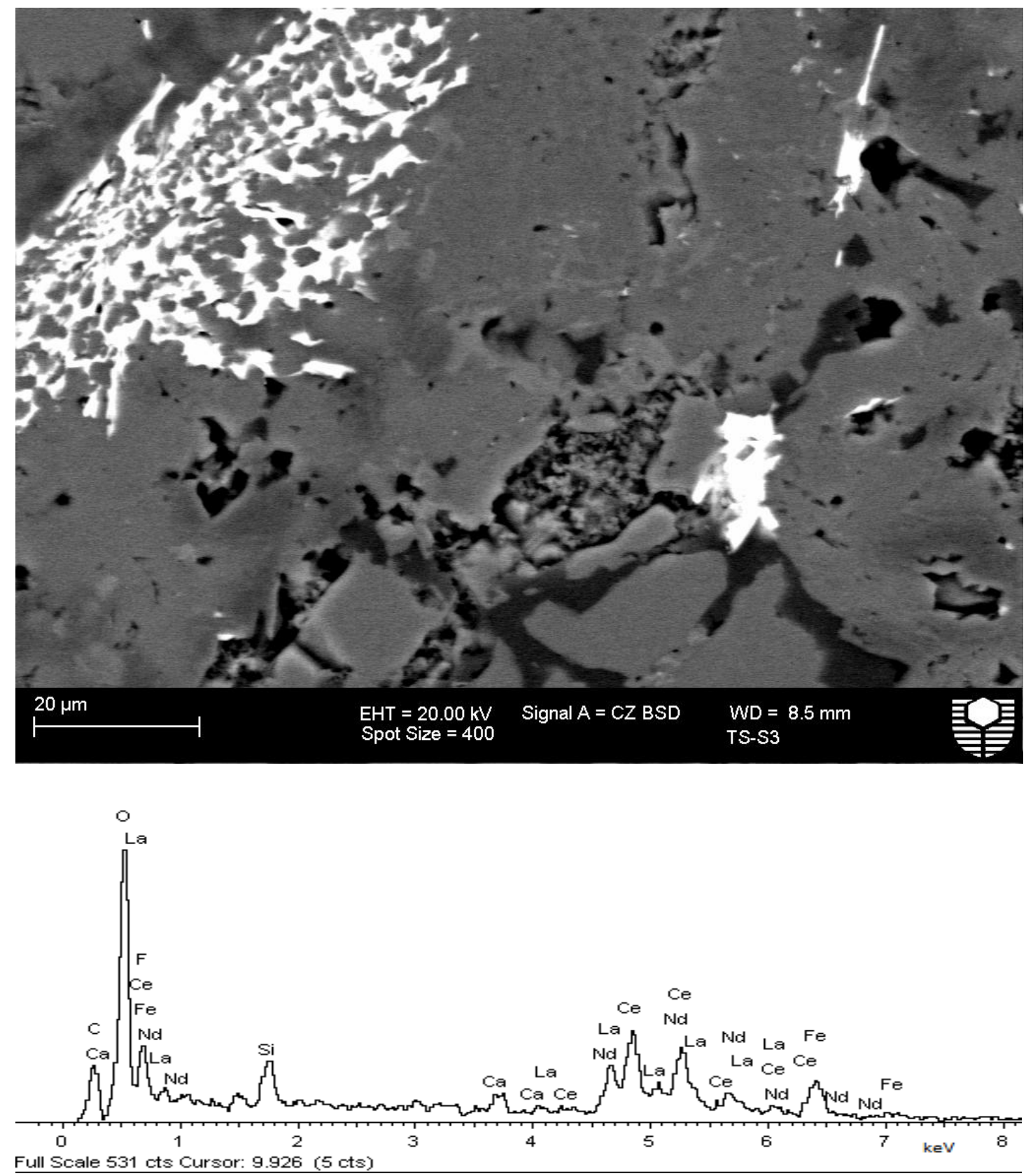

Fig. 2 Back-scattered SEM micrograph of bastnasite minerals in contrast with the dull-coloured silicate matrix with the EDS analysis shown at the bottom.

\subsection{Leaching Test}

The results of the leaching tests are summarized in Table 2 and showed strongly that conditions involving higher baking temperature (runs 5 to 8 ) produce higher $Y$ leaching at an average leaching rate of $79.9 \%$ as compared to lower temperature setting (runs 1-4) which only yielded average leaching rate of $44.6 \%$. On the other hand, grind size is affecting largely both La and Ce leaching where La and Ce average leaching rates are high at $95.3 \%$ and $95.0 \%$ respectively at finer grind size of 10 um (runs1,4,6 and 7) against $82.8 \%$ and $79.5 \%$ for La and Ce respectively at coarser grind size of 300 um (runs 2,3,5 and 8). The results also showed that $Y$ leaching rate is generally lower at an average of $62.3 \%$ as 
compared to La at $89.0 \%$ and $\mathrm{Ce}$ at $87.2 \%$ as brought about by the difficulty with which $\mathrm{Y}$ needs to be leached out from the fine-grained zirconosilicate minerals. At the highest leaching rate of $Y$ at $80.5 \%$ (run 5), the concentrations of rare earths in solution are as follows (in ppm): Y 290, La 659 and Ce 986.

Analysis of variance done at $95 \%$ confidence level showed that $\mathrm{Y}$ leaching is affected by many significant factors, listed herein in order of significance: baking temperature, baking time, acid dosage, leaching time and leaching temperature (Table 3). The high dependence of $Y$ leaching on the baking process supports that sulphation reaction requires the aid of temperature to increase acid diffusion and promote reaction of sulphate ions with $Y$ which is mostly entrained in the zirconosilicate grains.

La and Ce leaching on the other hand is affected mainly by grind size. This shows the very easy leaching characteristic of lanthanum. Cerium leaching showed dependence as well on baking temperature and baking time, highlighting the effect of temperature in aiding $\mathrm{Ce}$ leaching by breaking the flourocarbonate matrix in bastnasite mineral.

Main effects plot (Fig. 3) displays the data averages of leaching rates of $Y$, La and Ce and shows that the major factors affecting the leaching of rare earths are those factors related to the sulphation baking step. This can be seen clearly by the length of the lines for baking temperature, baking time and acid dosage, which are all favoured at high setting.

\begin{tabular}{|c|c|c|c|c|c|c|c|c|c|c|}
\hline \multicolumn{9}{|c|}{ Leaching conditions } & \multicolumn{3}{|c|}{ Leaching rate, \% } \\
\hline $\begin{array}{c}\text { Run } \\
\text { No }\end{array}$ & $\begin{array}{c}\text { Baking } \\
\text { temp } \\
\left({ }^{\circ} \mathrm{C}\right)\end{array}$ & $\begin{array}{c}\text { Baking } \\
\text { time } \\
(\mathrm{h})\end{array}$ & $\begin{array}{c}\text { Acid-ore } \\
\text { ratio } \\
(\mathrm{g} / \mathrm{g})\end{array}$ & $\begin{array}{c}\text { Leaching } \\
\text { time(h) }\end{array}$ & $\begin{array}{c}\text { Leaching } \\
\text { temp }\left({ }^{\circ} \mathrm{C}\right)\end{array}$ & $\begin{array}{c}\text { Water- } \\
\text { ore } \\
\text { ratio } \\
(\mathrm{mL} / \mathrm{g})\end{array}$ & $\begin{array}{c}\text { Grind } \\
\text { size } \\
(\mu \mathrm{m})\end{array}$ & $\mathrm{Y}$ & $\mathbf{L}$ & $\mathrm{Ce}$ \\
\hline $1-1$ & 200 & 1 & 0.4 & 1 & 20 & 5 & 10 & 36.06 & 91.97 & 90.92 \\
\hline $1-2$ & 200 & 1 & 0.4 & 1 & 20 & 5 & 10 & 40.05 & 92.73 & 92.11 \\
\hline $2-1$ & 200 & 1 & 0.4 & 3 & 70 & 20 & 300 & 32.41 & 87.05 & 78.03 \\
\hline $2-2$ & 200 & 1 & 0.4 & 3 & 70 & 20 & 300 & 27.67 & 85.92 & 75.16 \\
\hline $3-1$ & 200 & 3 & 3.2 & 1 & 20 & 20 & 300 & 64.16 & 81.32 & 79.58 \\
\hline $3-2$ & 200 & 3 & 3.2 & 1 & 20 & 20 & 300 & 61.57 & 83.53 & 80.65 \\
\hline $4-1$ & 200 & 3 & 3.2 & 3 & 70 & 5 & 10 & 54.06 & 96.29 & 95.83 \\
\hline $4-2$ & 200 & 3 & 3.2 & 3 & 70 & 5 & 10 & 41.06 & 96.20 & 95.44 \\
\hline $5-1$ & 320 & 1 & 3.2 & 1 & 70 & 5 & 300 & 81.94 & 80.63 & 80.60 \\
\hline $5-2$ & 320 & 1 & 3.2 & 1 & 70 & 5 & 300 & 79.00 & 73.49 & 73.58 \\
\hline $6-1$ & 320 & 1 & 3.2 & 3 & 20 & 20 & 10 & 73.78 & 97.31 & 97.13 \\
\hline $6-2$ & 320 & 1 & 3.2 & 3 & 20 & 20 & 10 & 83.00 & 98.46 & 98.34 \\
\hline $7-1$ & 320 & 3 & 0.4 & 1 & 70 & 20 & 10 & 80.21 & 94.39 & 94.87 \\
\hline $7-2$ & 320 & 3 & 0.4 & 1 & 70 & 20 & 10 & 80.97 & 95.08 & 95.15 \\
\hline $8-1$ & 320 & 3 & 0.4 & 3 & 20 & 5 & 300 & 78.68 & 85.29 & 84.12 \\
\hline $8-2$ & 320 & 3 & 0.4 & 3 & 20 & 5 & 300 & 81.53 & 84.90 & 84.15 \\
\hline
\end{tabular}

Table 2 Leaching test results showing leaching rates of $Y$, La and $\mathrm{Ce}$ 


\begin{tabular}{|c|c|c|c|c|c|c|}
\hline \multirow[t]{2}{*}{ Factor } & \multicolumn{3}{|c|}{ P-value } & \multicolumn{3}{|c|}{ Statistically optimized condition } \\
\hline & $\mathrm{Y}$ & La & $\mathrm{Ce}$ & $\mathrm{Y}$ & La & $\mathrm{Ce}$ \\
\hline baking temperature, ${ }^{\circ} \mathrm{C}\left(+/-20^{\circ} \mathrm{C}\right)$ & $2.50 E-07$ & 0.4998 & 0.033 & 320 & 200 & 320 \\
\hline baking time, $\mathrm{h}$ & 0.0011 & 0.2565 & 0.016 & 3 & 3 & 3 \\
\hline acid-ore dosage, g/g & 0.0019 & 0.2274 & 0.4228 & 3.2 & 0.4 & 0.4 \\
\hline leaching time, $\mathrm{h}$ & 0.0196 & 0.0011 & 0.0298 & 1 & 3 & 1 \\
\hline leaching temp, ${ }^{\circ} \mathrm{C}\left(+/-5^{\circ} \mathrm{C}\right)$ & 0.0479 & 0.4273 & 0.0479 & 20 & 20 & 20 \\
\hline water-ore ratio, $\mathrm{mL} / \mathrm{g}$ & 0.5399 & 0.0235 & 0.7904 & 20 & 20 & 20 \\
\hline grind size, $\mu \mathrm{m}$ & 0.3471 & $1.17 E-06$ & $2.62 E-07$ & 300 & 10 & 10 \\
\hline Significance level & 0.05 & 0.05 & 0.05 & & & \\
\hline Std deviation & 4.45 & 1.93 & 1.96 & & & \\
\hline $\begin{array}{l}\text { Leaching rate at optimized condition } \\
\text { for Y leaching (\%) }\end{array}$ & 91.3 & 93.5 & 93.4 & & & \\
\hline $\begin{array}{l}\text { Leaching rate at optimized condition } \\
\text { for La leaching (\%) }\end{array}$ & 64.6 & 98.8 & 94.7 & & & \\
\hline $\begin{array}{l}\text { Leaching rate at optimized condition } \\
\text { for Ce leaching (\%) }\end{array}$ & 89.8 & 95.4 & 94.7 & & & \\
\hline
\end{tabular}

Table 3 ANOVA table showing significant factors (italicised) base on P-values at 0.05 level of significance

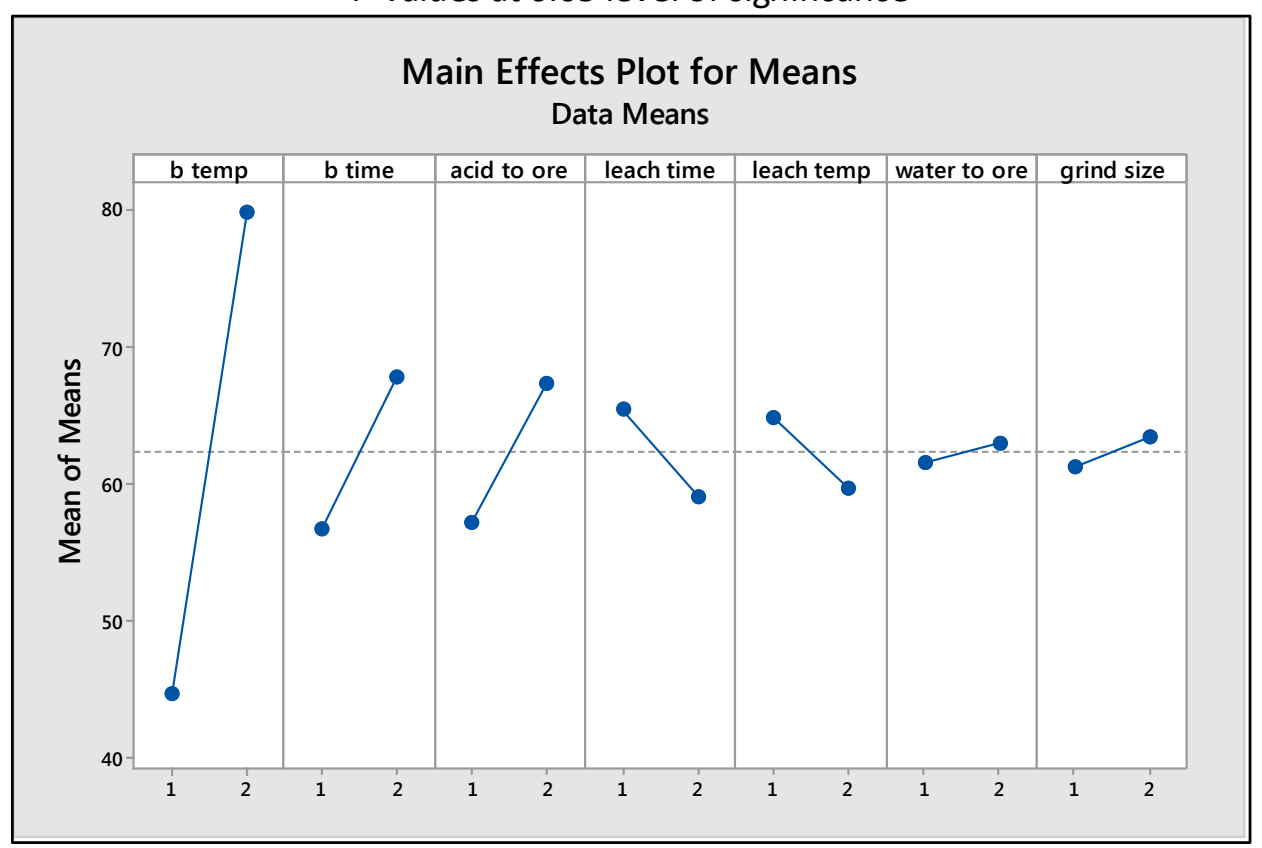

Fig. 3 Main effects plot showing sulphation baking step at high baking temperature, longer baking time and high acid to ore dosage as significant factors affecting leaching of rare earths from zirconosilicate ore 


\subsection{EFFECT OF FACTORS}

The effect of each leaching factor is studied by varying one factor at a time and conducting the leaching under the statistically optimized leaching condition for $Y$, being the main element of interest and consist of the following conditions: baking at $320^{\circ} \mathrm{C}$ for $3 \mathrm{~h}$ at $3.2 \mathrm{~g}$ acid/g ore followed by water leaching at $20^{\circ} \mathrm{C}$ for one $\mathrm{h}$ at $20 \mathrm{~mL} / \mathrm{g}$ dilution and $300 \mathrm{um}$ grind size. This condition was tested at laboratory and the leaching rate of rare earths was calculated as follows (\%): Y 91.3, La 93.5 and Ce 93.4.

\subsubsection{Effect of baking temperature}

The purpose of heating with concentrated sulphuric acid is to convert mineral species into water soluble sulphates. Normally, it is done either in low temperature acid baking $\left(<300^{\circ} \mathrm{C}\right)$ to effect solid-liquid reaction with sulphuric acid or by sulphation roasting at $400-700^{\circ} \mathrm{C}$ to induce gas -solid conversion reactions ${ }^{[22]}$. Acid baking is favoured in the treatment of low grade minerals like that of complex zirconosilicates $^{[23]}$. The chemical reactions involved in the conversion of complex zirconosilicate minerals into water soluble sulphates is believed to proceed via metal oxides attacked by sulphuric acid, as represented in the following formula ${ }^{[24]}$ :

$$
\begin{aligned}
& \mathrm{MO}_{\mathrm{x}}+\mathrm{xH}_{2} \mathrm{SO}_{4} \rightarrow \mathrm{M}\left(\mathrm{SO}_{4}\right)_{\mathrm{x}}+\mathrm{xH}_{2} \mathrm{O} \text { for solid-liquid reaction } \\
& \mathrm{MO}_{\mathrm{x}}+\mathrm{xSO}_{3}(\mathrm{~g}) \rightarrow \mathrm{M}\left(\mathrm{SO}_{4}\right)_{\mathrm{x}} \text { for solid-gas reaction }
\end{aligned}
$$

Baking temperature affects the amount of sulphuric acid that is available for sulphation. High temperatures cause loss of sulphuric acid by volatilization. Also, depending on the chemistry of the ore, baking temperature can be set objectively to promote chemical reactions needed for impurity control. For example, in treatment of rare earth ores with high thorium content like monazite, baking temperature is done above $300^{\circ} \mathrm{C}$ to promote the formation of insoluble $\mathrm{ThP}_{2} \mathrm{O}_{7}$ compounds ${ }^{[25]}$ at the expense of decreased leaching of rare earths due to loss of acid by volatilization. Most importantly, the thermal stresses induced by high temperature results to micro-fracturing and thus increase the specific surface area for reaction with sulphuric acid ${ }^{[26]}$. 


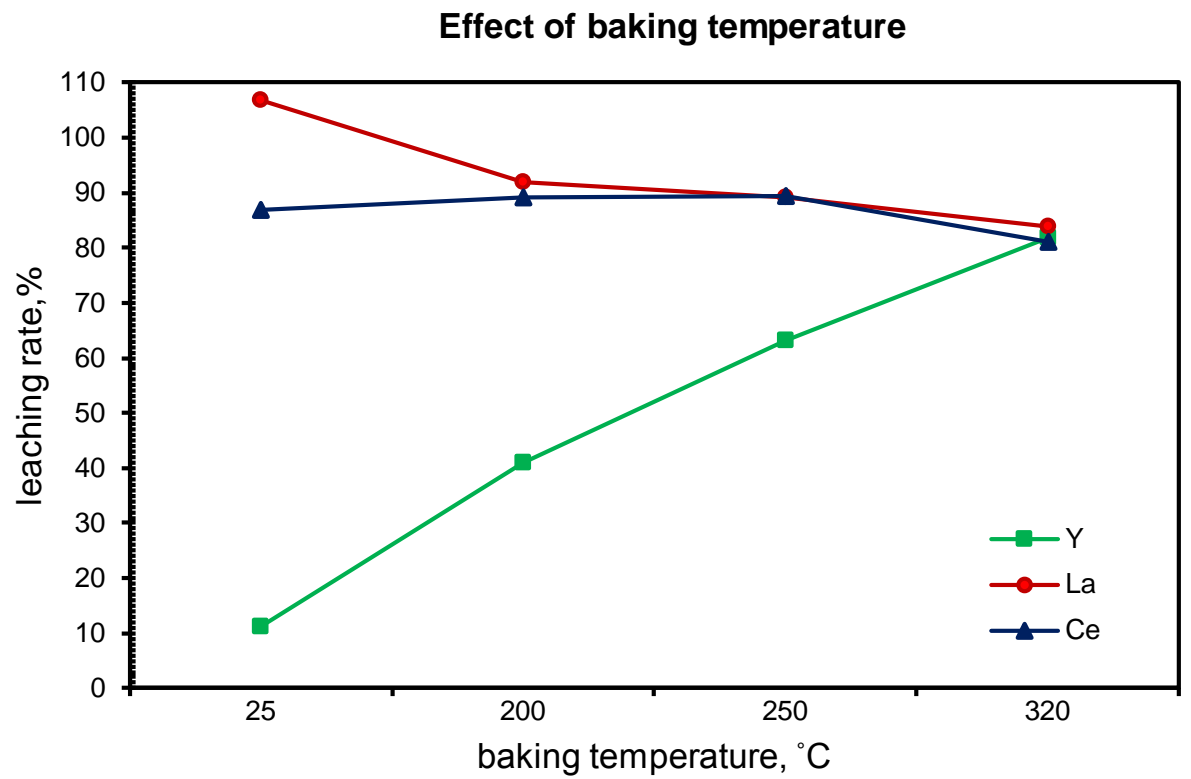

Fig. 4 Effect of baking temperature on leaching of $Y$, La \& Ce at leaching condition: $3 \mathrm{~h}$ baking time, $3.2 \mathrm{~g}$ acid $/ \mathrm{g}$ ore, $20^{\circ} \mathrm{C}$ leaching for $1 \mathrm{~h}, 20 \mathrm{~mL} / \mathrm{g}$ dilution, $300 \mathrm{um}$ grind size

Results of the leaching test (Fig. 4) showed that light rare earths La and Ce are very easy to dissolve that even an overnight soaking with concentrated sulphuric acid at ambient temperature attained higher leaching of these metals. Increasing the baking temperature above $200{ }^{\circ} \mathrm{C}$ resulted to a slight decrease in leaching. The behaviour is different for $Y$ in which leaching increases significantly with temperature with very poor leaching at $11.3 \%$ at room temperature but increased markedly to $41 \%$ at $200{ }^{\circ} \mathrm{C}$. At temperatures near the boiling temperature of sulphuric acid $\left(337^{\circ} \mathrm{C}\right), \mathrm{Y}$ leaching reaches $81.8 \%$ as brought about by a combination of sulphation reactions as outlined in equations 4 and 5 .

\subsubsection{Effect of baking time}

The effect of baking time on leaching was studied under statistically optimized leaching condition for $Y$. It was physically observed that the heated mass retained its original reddish brown colour after baking for $2 \mathrm{~h}$ while extended baking time at 3 and $4 \mathrm{~h}$ converted the ore mass to yellowish-white colour suggesting that chemical reactions with sulphuric acid has well proceeded under oxidising conditions. Prolonged baking time would result to sulphuric acid volatilisation and would effectively reduce the amount of sulphuric acid available for conversion of rare earth oxides to sulphates while shorter baking time would not ensure completeness of sulphation reaction with metals of interest. For example, after baking the ore for $1 \mathrm{~h}$, there was still liquid sulphuric acid left which reduces the filtration rate at the end of water leaching.

Highest leaching for $\mathrm{Y}$ is at $4 \mathrm{~h}$ while La and Ce has highest leaching at $3 \mathrm{~h}$ (Fig. 5). The relative difference between the leaching rates for La between time intervals is relatively low at less than $5 \%$, confirming that baking process is not a significant factor for La leaching. On the other hand, baking temperature is statistically determined as a significant factor for $\mathrm{Y}$. 


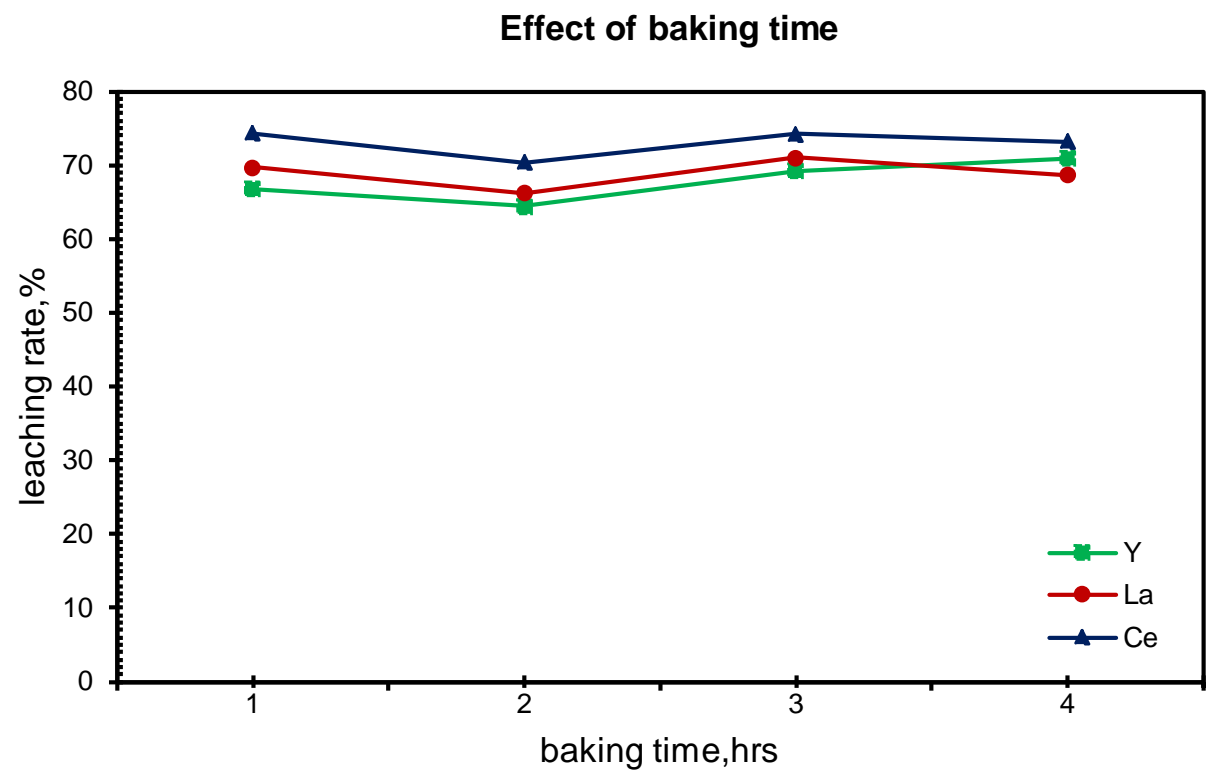

Fig. 5 Effect of baking time on leaching of $\mathrm{Y}$, La \& Ce at leaching condition: $320^{\circ} \mathrm{C}$ baking temp, $3.2 \mathrm{~g}$ acid/g ore, $20^{\circ} \mathrm{C}$ leaching for $1 \mathrm{~h}, 20 \mathrm{~mL} / \mathrm{g}$ dilution, 300 um grind size

\subsubsection{Effect of sulphuric acid to ore ratio}

Sulphuric acid to ore ratio is commonly calculated based on stoichiometric requirement and depends mainly on the chemistry of the ore as to which impurities react with sulphuric acid. This is to ensure that there is enough sulphuric acid to react with minerals for conversion to sulphates. For silicate minerals, an excess in terms of multiples of the stoichiometric requirement is provided to ensure co-leaching of silica is prevented ${ }^{[27]}$. This is believed to be accomplished by dehydrating the ore during decomposition ${ }^{[28]}$. A study on the thermal decomposition of rare earth sulphates showed that $\mathrm{Y}_{2}\left(\mathrm{SO}_{4}\right)_{3} \cdot 9 \mathrm{H}_{2} \mathrm{O}$ dehydrates at $195^{\circ} \mathrm{C}$ starting at $70^{\circ} \mathrm{C},\left(\mathrm{La}_{2}\left(\mathrm{SO}_{4}\right)_{3} \cdot 9 \mathrm{H}_{2} \mathrm{O}\right.$ undergoes dehydration at $256^{\circ} \mathrm{C}, \mathrm{Ce}_{2}\left(\mathrm{SO}_{4}\right)_{3} .2 \mathrm{H}_{2} \mathrm{O}$ at $90^{\circ} \mathrm{C}$ $140^{\circ}$ and $\mathrm{Ce}_{2}\left(\mathrm{SO}_{4}\right)_{3} \cdot 5 \mathrm{H}_{2} \mathrm{O}$ at $245^{\circ} \mathrm{C}^{[29]}$.

Earlier studies reported that the 8-10 folds excess of stoichiometric requirement is the best addition to increase the leaching of zirconium into solution ${ }^{[12,13,15]}$. For inclusion of RE recoveries, acid dosage at $500-750 \mathrm{~kg} / \mathrm{T}(0.5-0.75 \mathrm{~g} / \mathrm{g})$ of ore with REO content greater than $10 \%$ is common ${ }^{[4]}$. 


\section{Effect of acid to ore ratio}

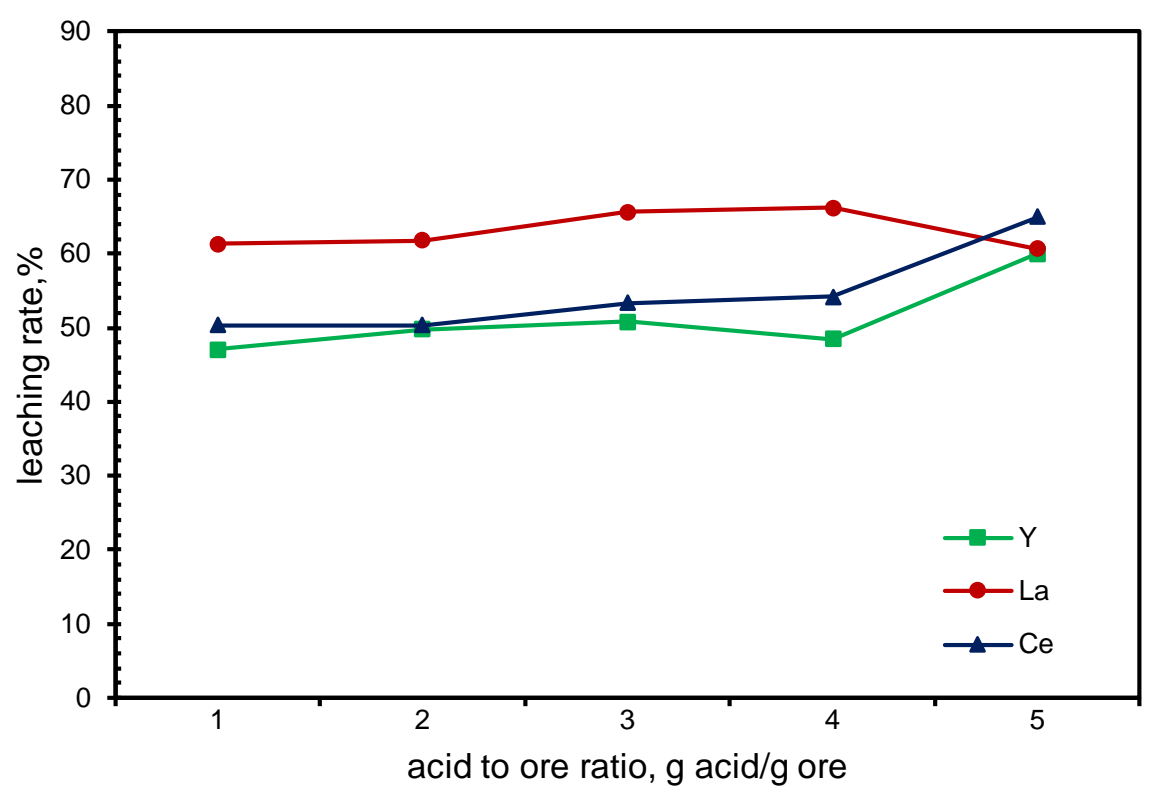

Fig. 6 Effect of acid to ore dosage on leaching of $\mathrm{Y}$, La \& Ce at leaching condition: $320^{\circ} \mathrm{C}$ baking temp, $3 \mathrm{~h}$ baking time, $20^{\circ} \mathrm{C}$, leaching for $1 \mathrm{~h}, 20 \mathrm{~mL} / \mathrm{g}$ dilution and $300 \mathrm{um}$ grind size

The acid dosage used in this experiment is extremely high as compared to reported practices. This was so as to ensure that there is enough sulphuric acid to react with increased surface area brought about by finer grind size of $10 \mathrm{um}$. Fig. 6 showed that there is an increasing trend of $Y$, La and Ce leaching with increased acid dosage particularly for $\mathrm{Y}$ and $\mathrm{Ce}$. This is related to the formation of more stable sulphate complexes with increased acid dosage. $\mathrm{Ce}$ (IV) for example, undergoes progressive hydrolysis with decrease sulphuric acid concentration forming metastable $\mathrm{H}_{2} \mathrm{Ce}(\mathrm{OH})_{2}\left(\mathrm{SO}_{4}\right)_{2}$ complex and subsequently precipitating out of solution as $\mathrm{HCe}(\mathrm{OH})_{2}\left(\mathrm{SO}_{4}\right)_{3}{ }^{[30]}$. A similar explanation is offered for the decrease in La solubility at the highest acid dosage tested.

\subsubsection{Effect of leaching temperature}

The leaching temperature dictates the leaching kinetics as well as the solubility of elements in solution. Plots of leaching for $Y$, La and Ce showed that solubility is higher at room temperature leaching as compared to heated leaching (Fig. 7). This can be explained by the heats of formation of rare earth sulphates in solution. The leaching of lanthanide sulphates and double sulphates is an exothermic reaction and consequently, its solubility decreases with increase in temperature ${ }^{[31-32]}$. Since the hydration of rare earth sulphates releases extra energy in the form of heat, the leaching process is inhibited ${ }^{[33]}$. This is the reason why water leaching of rare earth sulphates is carried out using cold water. High dilution is also used to reduce dissolved REE loss by adsorption into the leach residue ${ }^{[25]}$. 


\section{Effect of leaching temperature on dissolution}

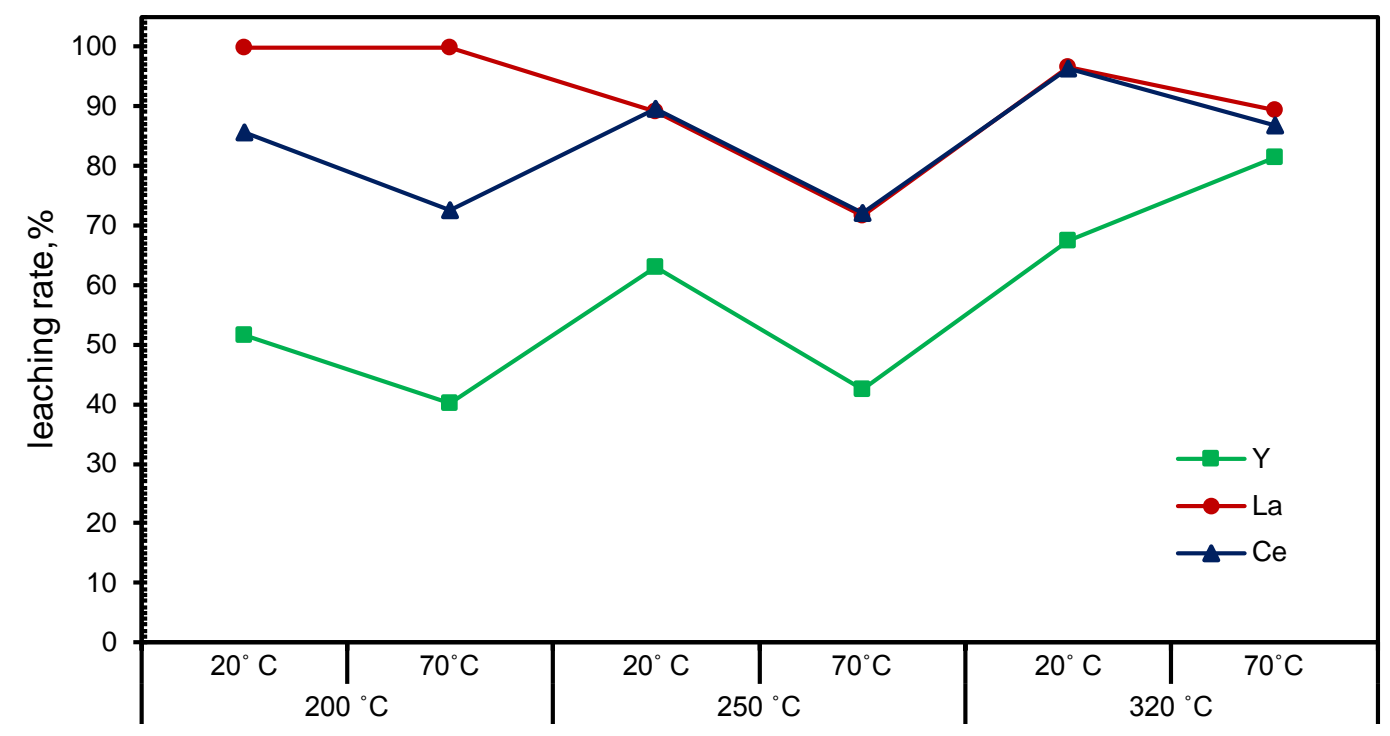

Fig. 7 Effect of leaching temperature on leaching of $Y$, La \& Ce at leaching condition: $3 \mathrm{~h}$ baking time, $3.2 \mathrm{~g} \mathrm{acid} / \mathrm{g}$ ore, $20 \mathrm{~mL} / \mathrm{g}$ dilution, $300 \mathrm{um}$ grind size

However, $\mathrm{Y}$ leaching at $320^{\circ} \mathrm{C}$ baking temperature behaves differently in that there is increased solubility at $70{ }^{\circ} \mathrm{C}$ leaching as compared to room temperature leaching. Such anomalous behaviour has been experienced in some sulphate systems such as in the case of neodymium where its solubility is increased at $64^{\circ} \mathrm{C}$. This was believed to be due to hydroxysulfate complexation resulting to a different enthalphy of leaching ${ }^{[30]}$.

\subsubsection{Effect of leaching time}

The effect of leaching time is studied at extreme intervals at 1, 2, 20 and $24 \mathrm{~h}$ where it can be seen that there is only a slight increase of $3 \%$ in the solubility of $\mathrm{Y}$ from $2 \mathrm{~h}$ leaching to $20 \mathrm{~h}$ after which it starts to drop (Fig. 8). The same pattern was observed for La and Ce solubility but the increase in solubility for prolonged leaching was higher at $15 \%$ as compared to $\mathrm{Y}$. The main disadvantage observed with prolonged leaching is the formation of silica films which reduces filtration by half the initial rate. The silica films were observed to be visible at $3 \mathrm{~h}$ of leaching and gradually coalesce into floating films becoming very visible after $10 \mathrm{~h}$ of leaching (Fig. 9). Due to this, the recommended leaching time is observed to be less than $3 \mathrm{~h}$, in expense of slight increase in leaching over time. 


\section{Effect of leaching time}

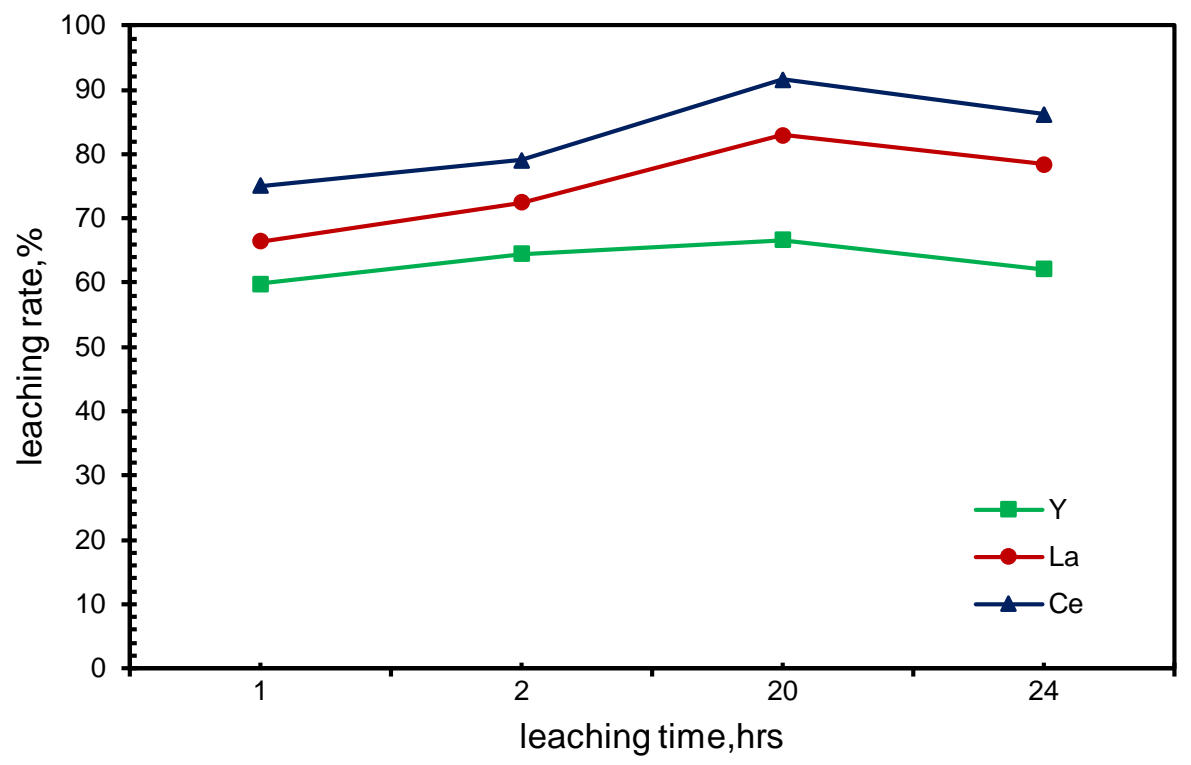

Fig. 8 Effect of leaching time on leaching of $Y$, La \& Ce at leaching condition: $320^{\circ} \mathrm{C}$ baking temp, $3 \mathrm{~h}$ baking time, $3.2 \mathrm{~g}$ acid $/ \mathrm{g}$ ore, $20^{\circ} \mathrm{C}$ leaching at $20 \mathrm{~mL} / \mathrm{g}$ dilution, 300 um grind size

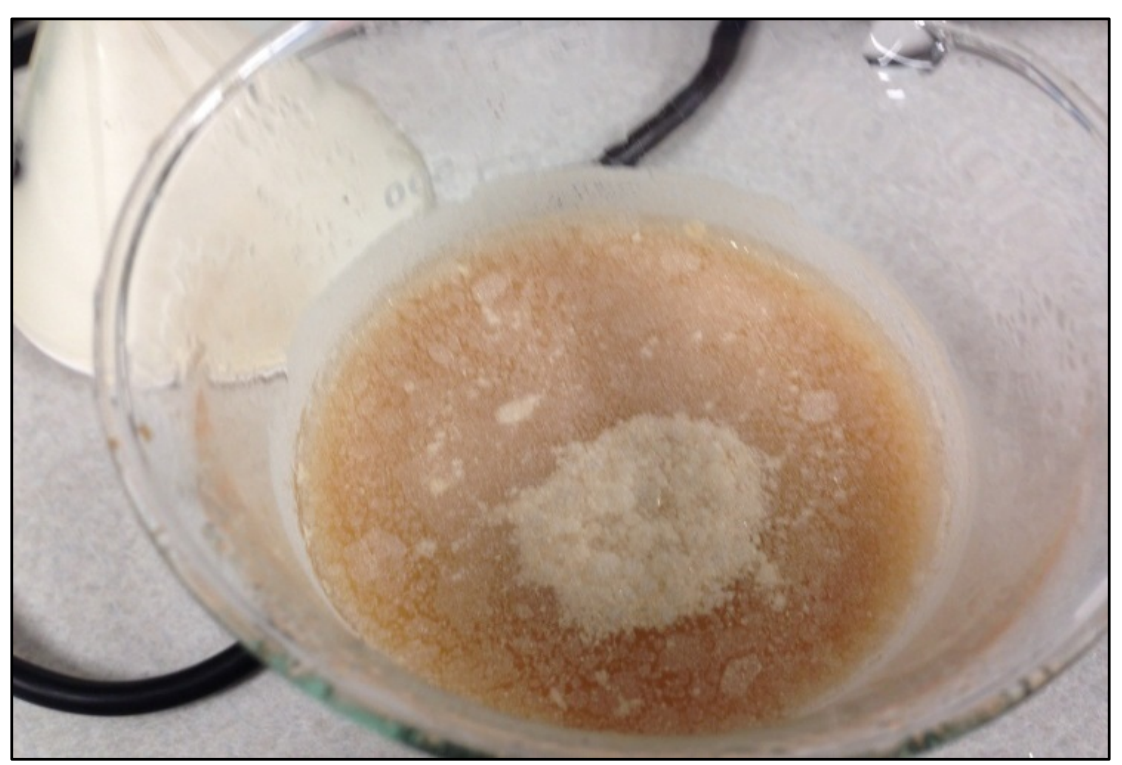

Fig. 9 Formation of silica films with extended leaching time of $20 \mathrm{~h}$ 


\subsubsection{Effect of dilution}

The effect of dilution on solubility is clearly shown to be in direct relationship with degree of leaching (Fig. 10). La and $\mathrm{Ce}$, being present in greater amount as compared to $\mathrm{Y}$, are mostly affected with the effect of dilution, with more than doubled leaching from $5 \mathrm{~mL} / \mathrm{g}$ to $10 \mathrm{~mL} / \mathrm{g}$ dilution. This is consistent with previous reports where higher dilution favours higher leaching due to the formation of stable hydrolysis products ${ }^{[34]}$. At low dilution, common ion effect lowers the solubility of La and Ce.

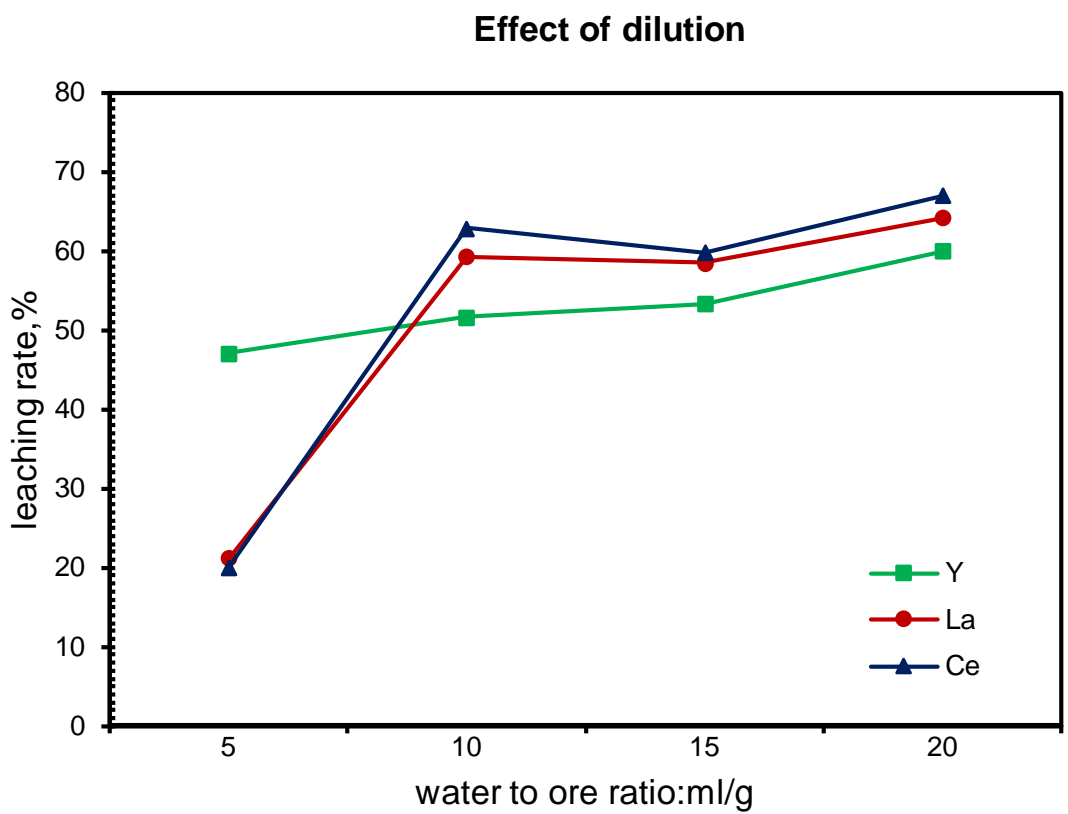

Fig. 10 Effect of dilution on leaching of $\mathrm{Y}, \mathrm{La} \& \mathrm{Ce}$ at leaching condition: $320^{\circ} \mathrm{C}$ baking temp, $3 \mathrm{~h}$ baking time, $3.2 \mathrm{~g}$ acid/ $\mathrm{g}$ ore, $20^{\circ} \mathrm{C}$ leaching for $1 \mathrm{hr}, 300 \mathrm{um}$ grind size

\subsubsection{Effect of grind size}

The effect of grind size on leaching showed that highest leaching of $Y$ occurs at coarser grind size of 300 um while La and Ce leaching is favoured with finer grind at $10 \mathrm{um}$, with trends of decreasing leaching with increasing grind size (Fig. 11). La and Ce are greatly affected with grind size as compared to other factors as determined by ANOVA (Table 3). As La and Ce occurs in relatively coarse-grained bastnasite minerals, its leaching is significantly affected by grind size by direct surface reaction of sulphuric acid with the bastnasite grains during sulphation and leaching. On the other hand, grind size is not a significant factor for $Y$. The inverse relationship of $Y$ leaching with grind size can be explained by a slight change in the crystal structure of the sample as it undergoes pulverization to finer grind size as evidence in the colour change from the original brownish colour at 75um to greyish colour at 10um grind size (pulverized by ISA mill, Fig. 12). The change in colour of the ground sample is more evident at 5um. Over grinding can effect crystal changes in some silicate materials and affect its leaching behaviour ${ }^{[35]}$. 


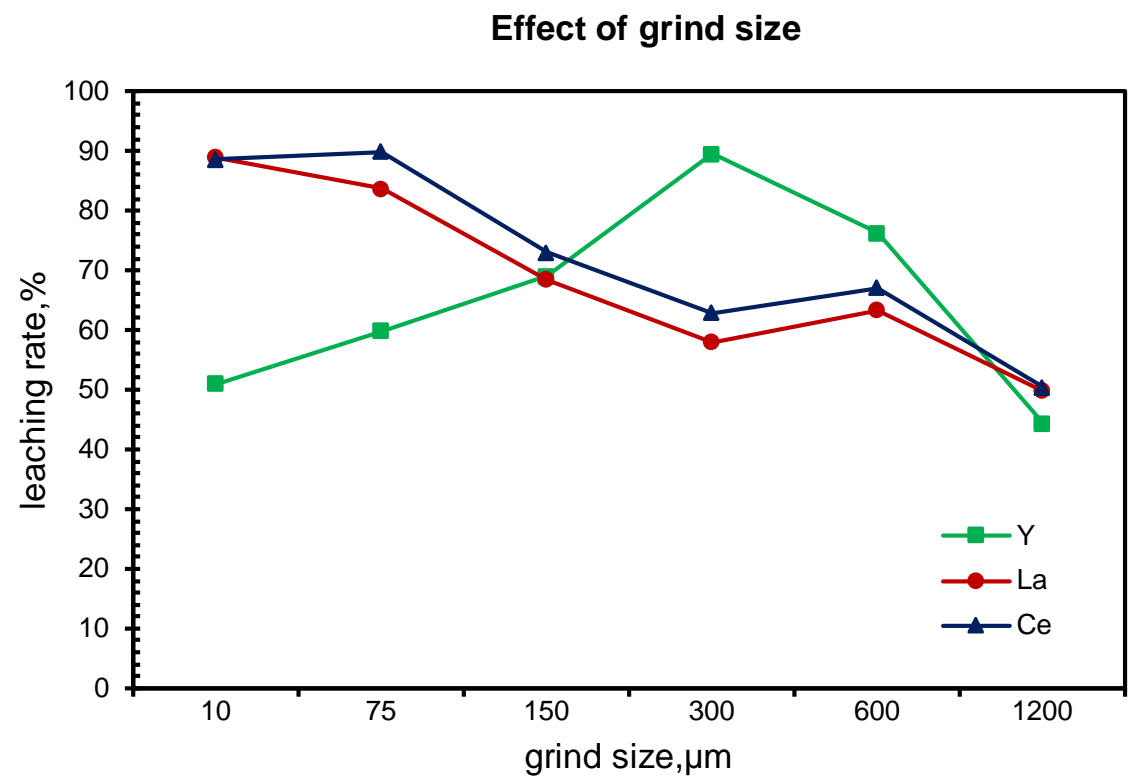

Fig. 11 Effect of grind size on leaching of $Y$, La $\&$ Ce at leaching condition: $320^{\circ} \mathrm{C}$ baking temp, $3 \mathrm{~h}$ baking time, $3.2 \mathrm{~g}$ acid $/ \mathrm{g}$ ore, $20^{\circ} \mathrm{C}$ leaching for $1 \mathrm{~h}, 20 \mathrm{~mL} / \mathrm{g}$ dilution

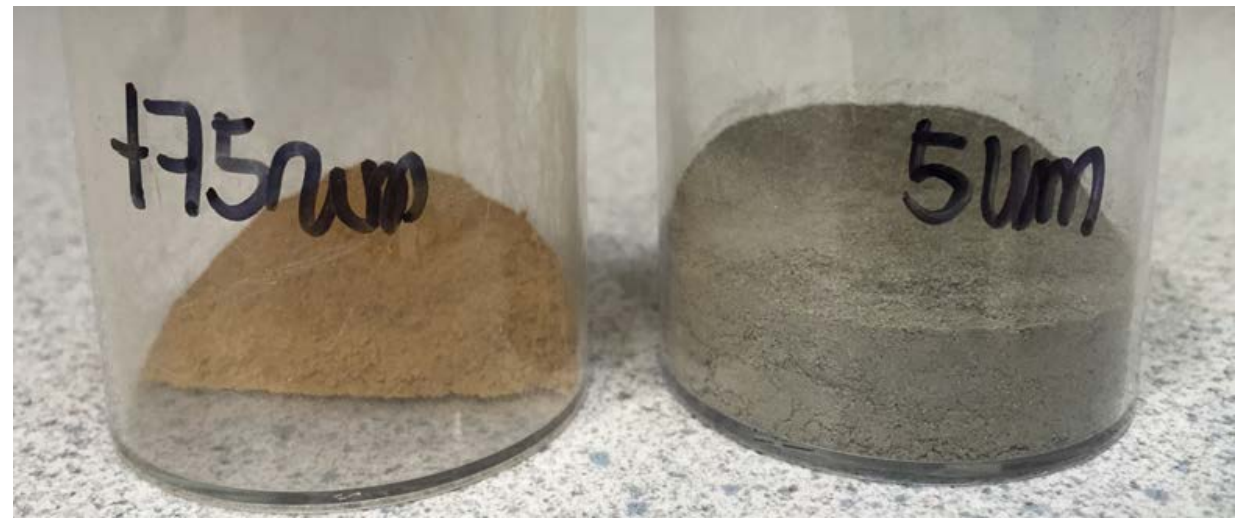

Fig. 12 Observed colour change of zirconosilicate ore with fine grinding to 5 um. 


\section{Co-leaching of impurities}

Host rock chemistry plays a vital role in any leaching process as impurities normally co-dissolved into the leaching solution, mostly with deleterious effect but with few cases of incurring favourable outcome. For instance, impurities always increase the acid requirement in leaching, however in the two-stage sulphuric acid leaching of eudialyte from Kola Peninsula, it was desired to maintain high levels of sodium sulphate in the leach solution for the effective separation of $\mathrm{Zr}$ and REE during the primary leaching stage ${ }^{[28]}$.

For silicate minerals though, the biggest concern is the co-dissolution of large amount of silica and its coagulation in solution. Silica gel hampers subsequent filtration and solvent extraction processes. Albeit, an analysis of the leach solution from various leaching conditions showed that only $\mathrm{Ca}$, $\mathrm{Mg}$ and $\mathrm{Fe}$ codissolve in relatively high percentages (Fig. 13). The co-dissolution of these elements increased significantly when the ore is subjected to sulphation baking and remains at high regardless if leaching is done at room or at elevated temperature. The concentration of these impurities at the highest dissolution are as follows (in mg/L): Ca 215, Fe 2320 and Mg 58. Interestingly, silica co-dissolution is minimal at less than $2 \%$ of the ore content. The average amount of silica in the unfiltered leach solution is $215 \mathrm{mg} / \mathrm{L}$ while filtration brings it down to $130 \mathrm{mg} / \mathrm{L}$ which is a low level for silica polymerization to occur. An effective method of rendering silica insoluble is by dehydration which can be done by starving the leaching system with water or by using strongly acidic leach solutions ${ }^{[36]}$. Treatment based on sulphation baking at high temperature and high acidity followed by water leaching effectively prevented the co-dissolution of large amount of silica. Other impurities Al, $\mathrm{Na}$ and $\mathrm{K}$ have low dissolution at less than $10 \%$ of the ore content with concentration at highest dissolution being (mg/L): Al 378, K 96 and $\mathrm{Na} 276$. The $\mathrm{pH}$ of the solution remained highly acidic at less than 0.5 during the leaching process.

\section{Dissolution of gangue elements}

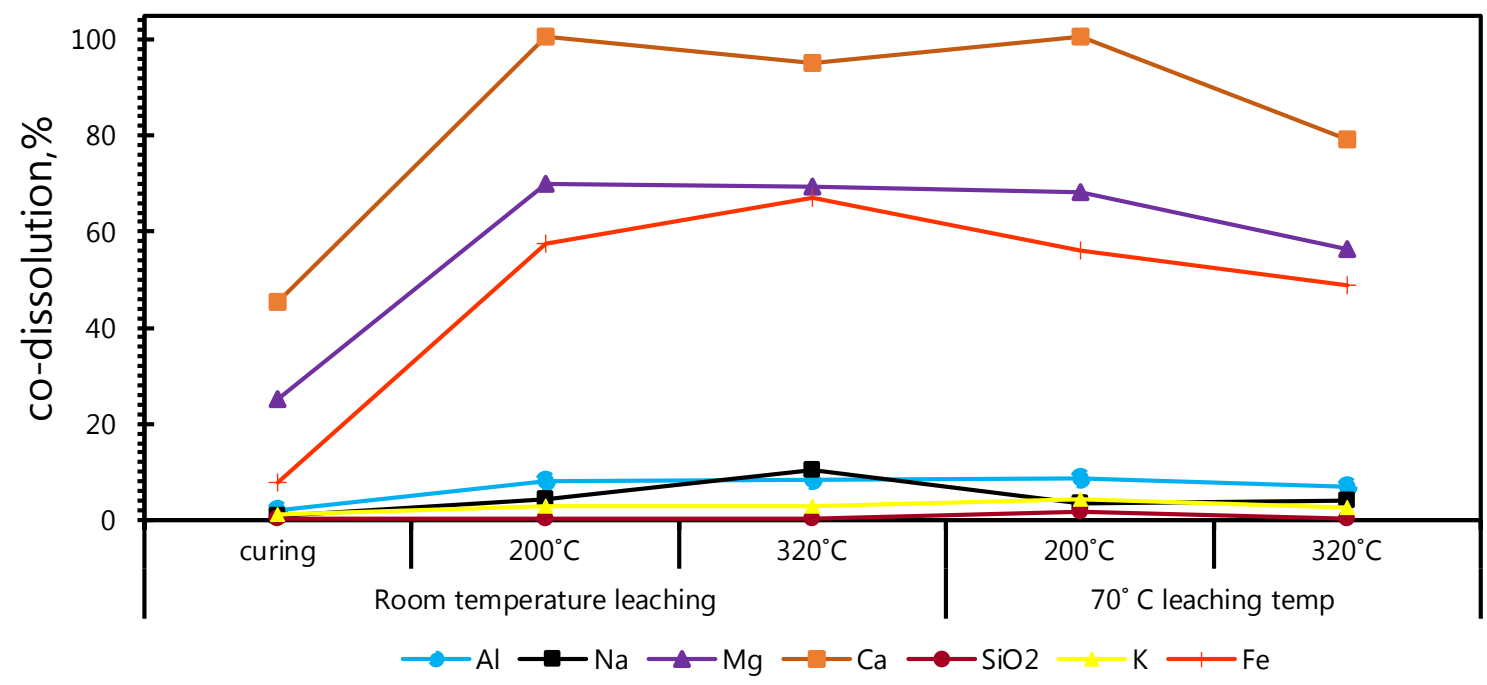

Fig. 13 Co-dissolution of impurities during leaching of fine-grained zirconosilicate ore at $3.2 \mathrm{~g} \mathrm{acid} / \mathrm{g}$ ore, $3 \mathrm{~h}$ baking and $1 \mathrm{~h}$ water leaching at $20 \mathrm{ml} / \mathrm{g}$ dilution and various baking and leaching temperature 


\section{Conclusion}

Sulphuric acid leaching of rare earths Y,La and Ce from fine-grained zirconosilicate ore required the leaching of whole-of-ground ore due to fineness of mineralization. Statistical analysis of the leaching test results showed that sulphation baking is a significant step for optimized leaching of rare earths and involves the following conditions: grinding the ore to $300 \mathrm{um}$, subjecting it to sulphation baking for $3 \mathrm{~h}$ at $320^{\circ} \mathrm{C}$ with acid dosage of $3.2 \mathrm{~g}$ acid/g ore followed by water leaching at $20^{\circ} \mathrm{C}$ for one $\mathrm{h}$ and at $20 \mathrm{~mL}$ water/g ore dilution. Further leaching test on effect of factors supports the statistical analysis done where it shows the increased leaching of $Y$ with increased baking temperature and increased acid dosage while La and Ce leaching is affected mainly by grind size. At these leaching condition, there is no significant dissolution of silica in the leach solution. 


\section{References}

[1] Kaczmarek J. Discovery and Commercial Separations. Industrial Applications of Rare Earth Elements. Washington DC:American Chemical Society,1981.Conference proceedings

[2] Chen,Z. Global rare earth resources and scenarios of future rare earth industry. J Rare Earth,2011,29(1):1-6.

[3] Hurst C. China's Rare Earth Elements Industry: What can the West Learn? : Institute for the Analysis of Global Security, Washington D.C.21 Jan 2015, http://www.iags.org/rareearth0310hurst.pdf.

[4] Lucas J, Lucas P, Le Mercier T, Rollat A, Davenport WG. Rare Earths Science,Technology,Production and Use. Amsterdam,Netherlands:Elsiever,2015.

[5] Ilyushin GD,Blatov VA. Crystal chemistry of zirconosilicates and their analogs: topological classification of MT frameworks and suprapolyhedral invariants. Acta Crystallogr Sect. B-Struct. Sci., 2002,58: 198-218.

[6] Pekov IV, Chukanov NV. Microporous Framework Silicate Minerals with Rare and Transition Elements: Minerogenetic Aspects. Rev Mineral Geochem, 2005,57: 145-171.

[7] Rastsvetaeva RK. Structural Mineralogy of the Eudialyte Group: A Review. Crystallogr Rep,2007,52(1):47-64.

[8] Sorensen H. Agpaitic nepheline syenites: a potential source of rare elements. Appl Geochem,1992, 7(5): 417-427.

[9] Sorensen H. (2001). The Ilimaussaq alkaline complex, South Greenland: status of mineralogical research with new results. Geol Greenl Surv Bull.2001,190: 1-67.

[10] Zubkova NV, Pushcharovsky DY. Mixed- Framework Microporous Natural Zirconosilicates. In S. Krivovichev (Ed.), Minerals as Advanced Materials. Berlin: Springer,2008.

[11] Olivo GR, Williams-Jones AE.Hydrothermal REE-rich Eudialyte from the Pilanesberg Complex, South Africa. Can Mineral,1999, 37: 653-663.

[12] Zakharov VI, Skiba GS, Sololev AV. Some aspects of eudialyte processing. Tsvetnye metally (in Russ), 2011,11:25-29.

[13] Lebedev VN, Shchur TE, Maiorov DV,Popova LA, Serkova RP. Specific Features of Acid Decomposition of Eudialyte and Certain Rare-Metal Concentrates from Kola Peninsula. Russian Journal of Applied Chemistry,2003, 76(8): 1191-1196.

[14] Lokshin EP,Tareeva OA,Kashulina TG.Desulfation of rare-earth concentrates. Russ J Appl Chem,2006,79(4):534-538.

[15] Zakharov VI,Maiorov DV, Alishkin AR,Matveev VA. Causes of insufficient recovery of zirconium during acidic processing of lovozero eudialyte concentrate. Russ J Non Ferr Met,2011,52(5):423428. 
[16] Furfaro, D., \& Krebs, D. Continuous leaching of Kvanefield Concentrate. Alta Conference. Perth, Western Australia,2014.

[17] Mackowski, S., Collier, D., Soldenhoff, K., \& Griffith, C. Hastings Project Process Development. Critical Minerals 2013. Perth, Western Australia,2013.

[18] Lin D. Making Full Use of Taguchi's Orthogonal Arrays. Qual Reliab Eng Int, 1994,10: 117-121.

[19] Taguchi G. System of Experimental Design. White Plains, New York: UNIPUB Kraus Intl Publications,1987.

[20] Taguchi G. Robust technology development. In W. Kuo (Ed.), Quality through engineering design (pp. 11-20). Netherlands: Elsevier,1993.

[21] Mitra A. Fundamentals of quality control and improvement. New Delhi,India: Pearson Educational Asia,1998.

[22] GuptaCK,Krishnamurthy N. Extractive Metallurgy Of Rare Earths.United States of America: CRC Press, 2005.

[23] Reveley S, Buchanan J, Forrester K, Cummings A. Review of Current Rare Earth Processing Practice. Alta Conference. Perth, Western Australia,2014.

[24] Agin J, Durupt N, Greco A, Hammy F, Laroche G, Thiry J. International Patent No. Patent Cooperation Treaty: W. I. P. Organization,2006.

[25] Zhang J, Edwards C. Mineral decomposition and leaching processes for treating rare earth ore concentrates. Can Metall Quart,2013,52(3): 243-248.

[26] Huang Y, Zhang T, Liu J, Dou Z, Tian J. Decomposition of the mixed rare earth concentrate by microwave-assisted method. J Rare Earth,2016,34(5):529-535.

[27] Terry B. The acid decomposition of silicate minerals part II. Hydrometallurgical applications. Hydrometallurgy, 1983,10(2): 151-171.

[28] Lebedev V. N.Sulfuric acid technology for processing of eudialyte concentrate. Russ J Appl Chem,2003,76(10): 1559-1563.

[29] Wendlandt W. The thermal decomposition of Ytrrium and the rare earth metal sulphate hydrates. J Inorg Nucl Chem,1958,7: 51-54.

[30] Paulenova A, Creager SE, Navratil JD, Wei Y. Redox potentials and kinetics of the $\mathrm{Ce} 3+/ \mathrm{Ce} 4+$ redox reaction and solubility of cerium sulfates in sulfuric acid solutions. I Power Sources, 2002,109(2), 431-438.

[31] Mellor J W.B,Al,Ga,In, TI,Sc,Ce and Rare Earths ( Part I)Comprehensive Treatise on Theoritical and Inorganic Chemistry. Toronto,Canada: Longmans, Green and Co. Ltd, 1924.

[32] Zelikmanc AW. Metallurgy of Rare Metals. Washington: US NASA and NSF Publication,1966. 
[33] Averill BA,Eldredge P. Effects of Temperature and Pressure on Solubility.Chemistry: Principles,Patterns, and Applications Vol 1. Prentice Hall, 2006.

[34] Moeller T. Observations on the Rare Earths. LV. Hydrolysis Studies upon Yttrium, and Certain Rare Earth(III) Sulfate Solutions at $25^{\circ} \mathrm{C}$. J Phys Chem,1946, 50(3): 242-250.

[35] Chizhevskaya S, Chekmarev A, Kilmenko OM, Povetkina MV, Sinegribiva OA, Cox M. Nontraditional methods of treating high-silicon ores containing rare elements. Hydrometallurgy.Netherlands,1994.

[36] Terry B. The acid decomposition of silicate minerals part I. Reactivities and modes of dissolution of silicates . Hydrometallurgy, 1983,10(2): 135-150.

\section{Acknowledgement}

The authors acknowledge the use of Curtin University's Microscopy \& Microanalysis Facility, whose instrumentation has been partially funded by the University, State and Commonwealth Governments. 


\section{Graphical Abstract}

Back-scattered SEM micrograph showing fine-grained zirconosilicate minerals (a) and main effects plot from means of leaching rates (b)

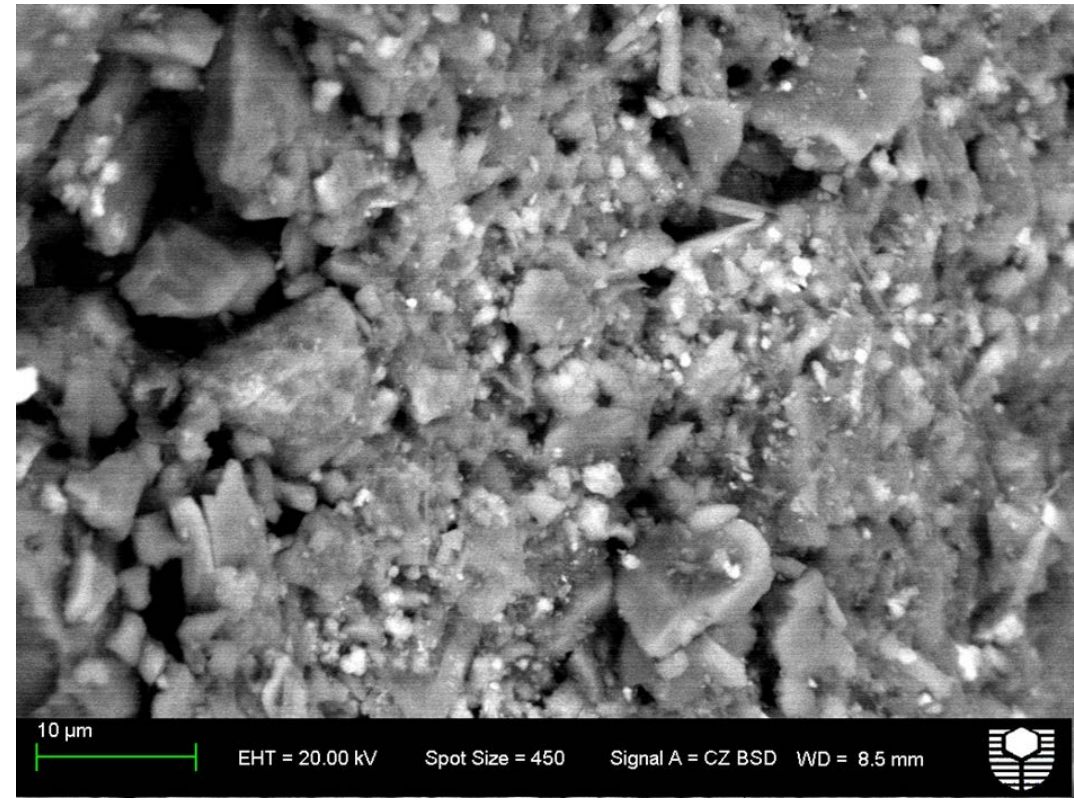

(a)

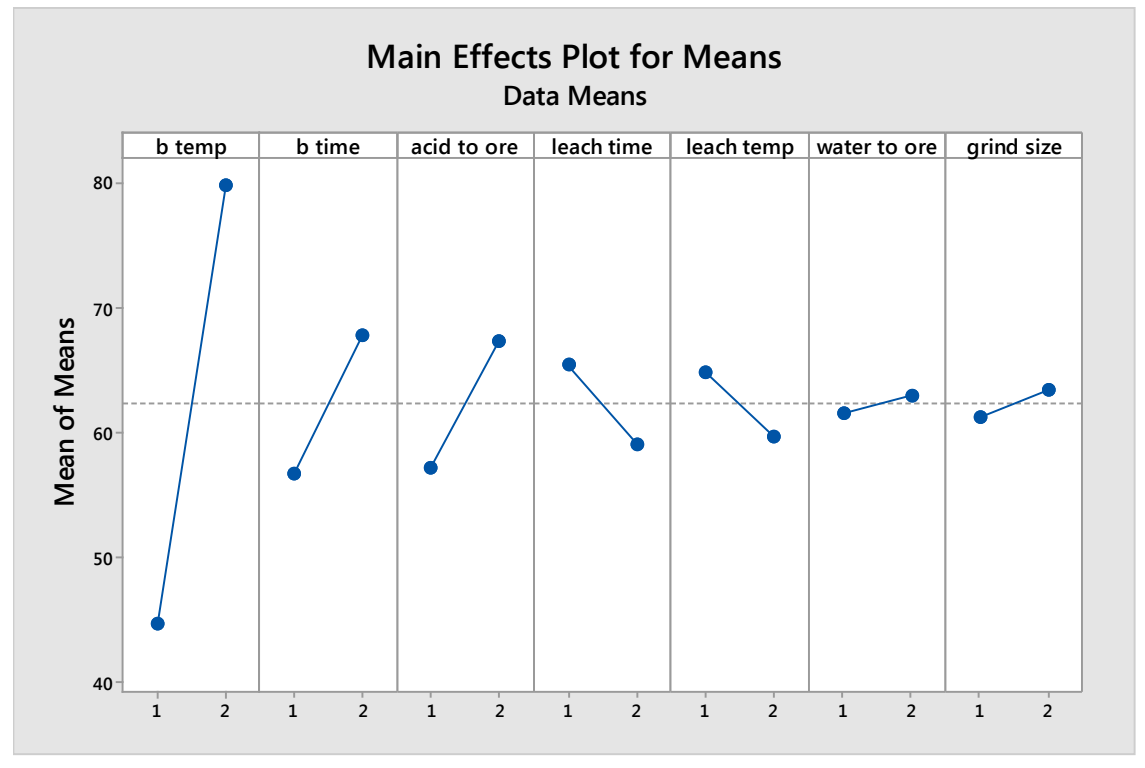

(b) 